\title{
STUDIES ON ALBUMIN SYNTHESIS: THE EFFECTS OF DEXTRAN AND CORTISONE ON ALBUMIN METABOLISM IN RABBITS STUDIED WITH ALBUMIN-I ${ }^{131} *$
}

\author{
By MARCUS A. ROTHSCHILD, MURRAY ORATZ, ERNEST WIMER AND \\ SIDNEY S. SCHREIBER WITH THE TECHNICAL ASSISTANCE OF \\ ROBERT QUESENBERRY AND DOUGLAS FAISON \\ (From the Radioisotope Service, Veterans Administration Hospital, the Department of Medi- \\ cine, New York University School of Medicine, and the Department of Biochemistry, \\ New York University College of Dentistry, New York, N. Y.)
}

(Submitted for publication September 7, 1960; accepted November 21, 1960)

Following plasmapheresis, the depressed serum albumin concentration rapidly returns to normal (1) indicating alterations in albumin synthesis or degradation. Both dextran administration (2-6) and elevation of serum globulin levels produced by means of hyperimmunization $(7,8)$ are associated with hypoalbuminemia; a colloid osmotic regulatory mechanism has been suggested as responsible for the reciprocal changes in serum proteins observed after hyperimmunization $(7,9)$. If such a mechanism does exert control over the concentration of serum albumin, alterations of albumin metabolism either in the rate of synthesis or in the rate of degradation might be expected when osmotically active molecules other than albumin are added to the circulation. The present study represents an attempt to define, more specifically than heretofore reported, the changes in albumin metabolism resulting from such a procedure. Dextran was administered to rabbits to depress albumin concentration. After the development of hypoalbuminemia, the rates of albumin synthesis and degradation were studied and compared with control values. Cortisone acetate was then given to increase the rate of albumin degradation (10), and the rates of albumin synthesis were remeasured.

\section{METHODS}

Female rabbits were used in all studies. Animals were kept in metabolism cages and fed a standard rabbit diet. Lugol's solution was added to the drinking water daily

The distribution and metabolism of albumin were

* This material was presented in part at the meeting of the Eastern Section of the American Federation for Clinical Research on December 10, 1959. This investigation was supported in part by Grant no. A-2489 from the United States Public Health Service. studied by means of $\mathrm{I}^{131}$-labeled rabbit serum albumin. Assays of $\mathrm{I}^{131}$ in plasma, stool and urine were made for a control period of 10 to 14 days following intravenous administration of albumin- $\mathrm{I}^{131}$. Following the control period, 1.0 to $1.5 \mathrm{~g}$ of dextran (Laros, lot $\mathrm{H}$., average molecular weight 188,000) dissolved in $20 \mathrm{ml} 0.9$ per cent saline was injected i.v., once daily in 10 animals. After 15 to 30 days, the animals received a second injection of albumin- ${ }^{132}$ while the daily dextran infusions were continued, and observations were continued for another 12 to 18 days. Six of the 10 animals were then started on cortisone acetate $(3 \mathrm{mg}$ per $\mathrm{kg}$ per day, s.c.) and dextran infusions were continued for another 9 to 14 days. At the end of this period a third injection of albumin- $\mathrm{I}^{131}$ was made to remeasure albumin synthesis, degradation and pool size. ${ }^{1}$ In two other rabbits, cortisone and dextran were administered simultaneously from the beginning of the study for a period of 15 days. Two other animals were infused with $20 \mathrm{ml}$ of 0.9 per cent saline for 15 and 24 days. Two of the animals receiving dextran alone were studied again with albumin$\mathrm{I}^{131} 6$ and 8 weeks after the termination of the original studies to determine whether the prolonged dextran infusions had had any lasting effects on albumin synthesis. During periods of cortisone administration rabbits received $0.25 \mathrm{~g}$ streptomycin and 75,000 $\mathrm{U}$ procaine penicillin intramuscularly every other day and 5 to $8 \mathrm{mEq}$ potassium chloride in the water daily, of which the animals consumed 2 to $3 \mathrm{mEq}$ per day. Injections of albumin- $\mathrm{I}^{131}$ were made into an ear vein. Five- to eighttenths $\mathrm{ml}$ heparinized venous blood was obtained from the opposite ear 6 and 10 minutes after injection, at daily intervals for 1 week, and every second or third day thereafter. Blood samples taken for assay were obtained just prior to the daily injections of dextran.

Rabbit albumin was separated from whole serum as previously described (10) and occasional lots of rabbit albumin preparation, no. 7305,2 were employed after re-

\footnotetext{
1 Reinjections of albumin- $\mathrm{I}^{131}$ were made at such time intervals and dose levels that the residual activity from previous injections was negligible and did not affect the subsequent calculations.

2 Purchased from Pentex Inc., Kankakee, Illinois.
} 
A

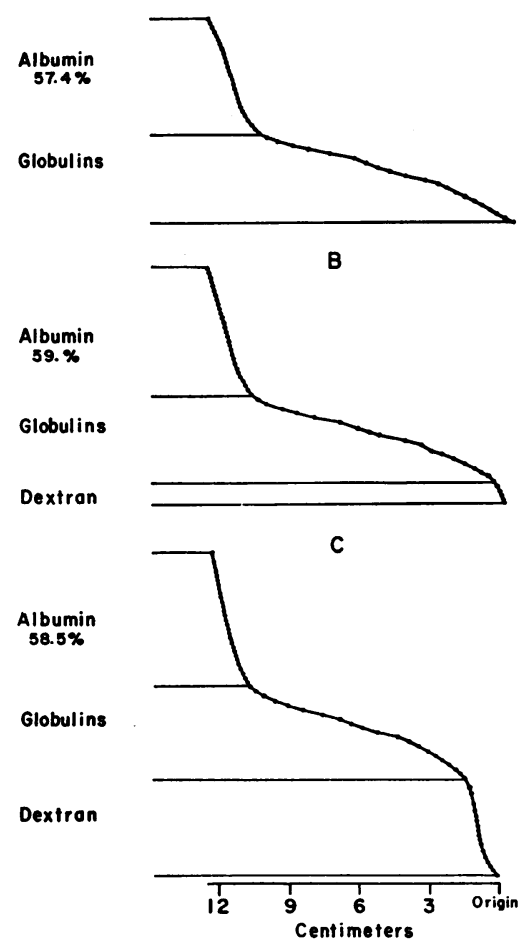

Fig. 1. Concentration Crossplots OF THE INTERFEROMETRIC PATTERNS OF RABBIT SERUM ( $3.50 \mathrm{~g} / 100 \mathrm{ML}$ ) INCUBATED WITH THE DEXTRAN CONCENTRATION VARYING FROM 0 (A), $1.20 \mathrm{~g} / 100 \mathrm{ML}$ (B), AND $2.25 \mathrm{G} / 100 \mathrm{ML}$ (C). SEE TEXT. purification. The $\mathrm{I}^{131}$-labeling procedure has been described previously (11). All lots of albumin- ${ }^{131}$ were tested in normal control animals to insure against the use of a lot that contained any significant amounts of denatured labeled protein (10).

Dextran solutions were prepared by dissolving $120 \mathrm{~g}$ in $1,500 \mathrm{ml}$ of normal saline and filtered through a bacterial filter. Plasma dextran concentrations were determined by the method of Roe (12). Urine was tested for protein by precipitation with cold 20 per cent trichloroacetic acid.

Plasma, urine and stool samples were assayed for radioactivity in a well-type scintillation counter with a sensitivity of $9.7 \times 10^{5} \mathrm{cpm}$ per $\mu \mathrm{c} \mathrm{I}^{131}$ above a background of $170 \mathrm{cpm}$. Total plasma protein was determined by a micro-Kjeldahl method. Concentration of plasma albumin was determined by boundary electrophoresis with a Kern microelectrophoresis apparatus. In this method, $0.2 \mathrm{ml}$ serum or plasma was diluted to $0.8 \mathrm{ml}$ with Michaelis-veronal buffer at $\mathrm{pH} 8.6$ and the solution was dialyzed against the buffer for 30 minutes prior to electrophoresis for 40 minutes at $80 \mathrm{v}$. The presence of dextran did not interfere with the determination, since the albumin fraction remained constant at dextran concentrations ranging from 0.1 to $2.0 \mathrm{~g}$ per $100 \mathrm{ml}$. Dextran itself resulted in a clearly differentiated interference pattern at the initial boundary (Figure 1).

Plasma volume was determined from the space of distribution of albumin- $\mathrm{I}^{131}$ at 6 and 10 minutes after injection. Total exchangeable albumin and the extravascular: intravascular distribution of albumin were determined as previously described (11). The rate of albumin metabolism during the control period was determined from

TABLE I

Albumin distribution *

\begin{tabular}{|c|c|c|c|c|c|c|c|c|c|c|c|c|c|c|c|}
\hline \multirow[b]{2}{*}{ Animal } & \multicolumn{3}{|c|}{ Weight } & \multicolumn{3}{|c|}{ Hematocrit } & \multicolumn{3}{|c|}{ Plasma volume } & \multicolumn{3}{|c|}{ TEAS } & \multicolumn{3}{|c|}{ Albumin partition } \\
\hline & $\mathbf{N}$ & D & $\mathrm{D}+\mathrm{C}$ & $\mathrm{N}$ & D & $\mathrm{D}+\mathrm{C}$ & $\mathbf{N}$ & D & $\mathrm{D}+\mathrm{C}$ & $\mathbf{N}$ & D & $\mathrm{D}+\mathrm{C}$ & $\mathrm{N}$ & $\mathrm{D}$ & $\mathrm{D}+\mathrm{C}$ \\
\hline & \multicolumn{3}{|c|}{$k g$} & \multicolumn{3}{|c|}{$\%$} & \multicolumn{3}{|c|}{$m l / k g$} & \multicolumn{3}{|c|}{$m g l / k g$} & \multicolumn{3}{|c|}{$\%$ intravascular } \\
\hline $\begin{array}{c}4 \\
6 \\
9 \\
16 \\
22 \\
7 \\
10 \\
11 \\
18 \dagger \\
46 \\
21 \\
24\end{array}$ & $\begin{array}{l}4.08 \\
3.63 \\
5.45 \\
6.46 \\
5.05 \\
4.08 \\
4.78 \\
5.23 \\
3.87 \\
4.54 \\
5.94 \\
5.24\end{array}$ & $\begin{array}{l}4.08 \\
3.86 \\
5.45 \\
6.37 \\
5.91 \\
4.66 \\
4.54 \\
5.00 \\
4.54 \\
4.54\end{array}$ & $\begin{array}{l} \\
\\
5.23 \\
4.32 \\
4.20 \\
4.78 \\
4.10 \\
4.66 \\
5.54 \\
5.13\end{array}$ & $\begin{array}{l}36.8 \\
38.6 \\
33.6 \\
39.0 \\
37.8 \\
37.8 \\
35.6 \\
42.3 \\
43.0 \\
32.0 \\
39.8 \\
36.3\end{array}$ & $\begin{array}{l}28.5 \\
25.8 \\
24.5 \\
32.7 \\
27.0 \\
23.8 \\
23.2 \\
29.6 \\
33.0 \\
25.2\end{array}$ & $\begin{array}{l}29.2 \\
18.3 \\
18.4 \\
22.0 \\
25.8 \\
18.5 \\
26.4 \\
23.6\end{array}$ & $\begin{array}{l}27.9 \\
37.8 \\
34.5 \\
29.1 \\
30.9 \\
38.0 \\
29.7 \\
24.6 \\
33.6 \\
35.5 \\
28.3 \\
33.2\end{array}$ & $\begin{array}{l}34.8 \\
47.2 \\
45.0 \\
35.2 \\
33.8 \\
41.4 \\
40.4 \\
35.2 \\
36.8 \\
42.8\end{array}$ & $\begin{array}{l}57.9 \\
82.5 \\
66.6 \\
58.5 \\
59.6 \\
53.0 \\
60.5\end{array}$ & $\begin{array}{r}74.5 \\
94.5 \\
86.6 \\
70.4 \\
77.8 \\
100.5 \\
77.8 \\
69.1 \\
93.4 \\
100.0 \\
76.4 \\
86.5\end{array}$ & $\begin{array}{r}105.8 \\
126.5 \\
112.5 \\
90.0 \\
109.0 \\
119.0 \\
126.6 \\
108.2 \\
98.0 \\
122.0\end{array}$ & $\begin{array}{l}131.0 \\
171.5 \\
174.5 \\
127.5 \\
132.0 \\
165.0 \\
114.2 \\
133.8\end{array}$ & $\begin{array}{l}37.4 \\
40.1 \\
39.8 \\
41.4 \\
39.7 \\
37.9 \\
38.2 \\
35.6 \\
36.6 \\
36.2 \\
37.3 \\
38.4\end{array}$ & $\begin{array}{l}33.0 \\
37.4 \\
40.1 \\
39.2 \\
31.0 \\
34.8 \\
31.8 \\
32.5 \\
37.6 \\
35.1\end{array}$ & $\begin{array}{l}44.4 \\
48.2 \\
38.3 \\
\\
44.4 \\
36.2 \\
46.4 \\
45.2\end{array}$ \\
\hline Mean value & 4.86 & 4.90 & 4.75 & 37.7 & 27.3 & 22.8 & 31.9 & 39.3 & 62.7 & 84.0 & 111.8 & 143.7 & 38.2 & 35.3 & 43.3 \\
\hline$\pm \mathrm{SE}$ & & & & 0.9 & 1.1 & 1.5 & 1.2 & 1.6 & 3.7 & 3.1 & 3.8 & 8.8 & 0.5 & 1.0 & 1.7 \\
\hline p Value & & & & & $<0.001$ & $<0.001$ & & $<0.001$ & $<0.001$ & & $<0.001$ & $<0.001$ & & $<0.02$ & $<0.001$ \\
\hline $\begin{array}{l}\text { Per cent chan } \\
(N-D) / N\end{array}$ & & & & & -27.6 & & & +23.2 & & & +33.1 & & & -7.6 & \\
\hline $\begin{array}{l}\text { Per cent chan } \\
D-(D+C) / I\end{array}$ & & & & & & -16.5 & & & +59.5 & & & +28.5 & & & +22.7 \\
\hline
\end{tabular}

* TEAS = total exchangeable albumin space. $\quad \mathrm{N}=$ control study. $\mathrm{D}=$ dextran study. $\mathrm{D}+\mathrm{C}=$ dextran and cortisone study. SE $=$ standard error of the mean. All $p$ values are based on comparisons between the control (N) and experiment values (D and $D+C)$.

comeritran study. The experimental periods, however, are compared with the initial control values. 


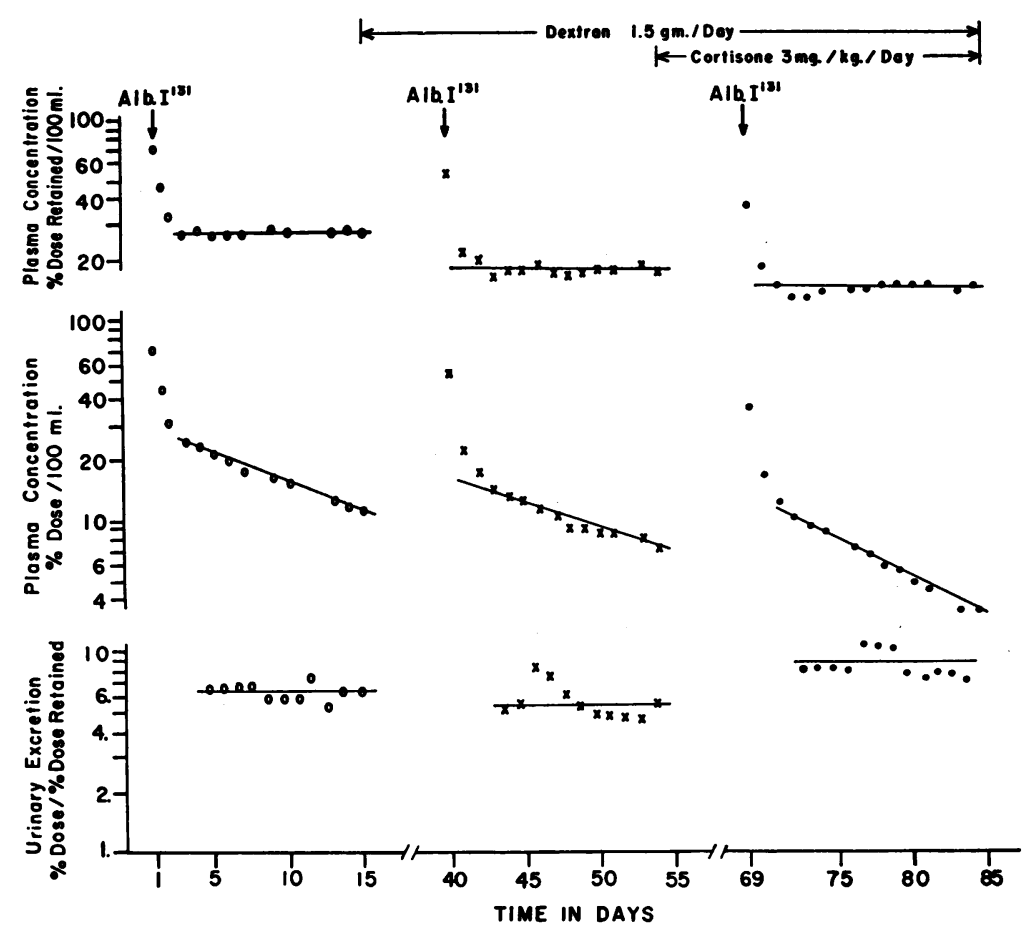

Fig. 2. Typical Set of curves (Rabbit 10) Showing distribution, PLASMA DECAY, AND URINARY EXCRETION CURVES DURING THE CONTROL PERIOD AND FOLLOWING THE ADMINISTRATION OF DEXTRAN AND DEXTRAN AND CORTISONE.

the product of the clearance of plasma- ${ }^{131}$ and the plasma albumin concentration. This technique has been described in detail in previous reports $(10,13,14)$. It has been demonstrated that the clearance method can be applied in nonsteady state conditions $(10,13,15)$. The total amount of albumin degraded over each period was obtained from the sum of the daily values of the amount of albumin degraded, as determined by the clearance method. During the control periods, the plasma albumin concentrations remained constant, and it may be assumed that steady state conditions, with respect to albumin metabolism, were satisfied, and that the quantity of albumin synthesized was equal to the quantity degraded. In previous studies the amount of albumin synthesized during an experimental period was calculated from the difference between the total amount degraded and the change in the total exchangeable albumin pool during the period. In this study the rabbits were "equilibrated" with the test substances before reinjection, and the experimental data for albumin degradation were derived from subsequent injections of albumin- $\mathrm{I}^{121}$. Since the plasma albumin values changed only slightly following the reinjections, albumin synthesis was assumed to closely parallel albumin degradation. These observations do not permit an exact evaluation of degradation or synthesis during the period of equilibration prior to reinjection of albumin- $\mathrm{I}^{131}$. However, the control and experimental values for albumin degradation and the changes in pool size are known and indicate the net albumin bal-

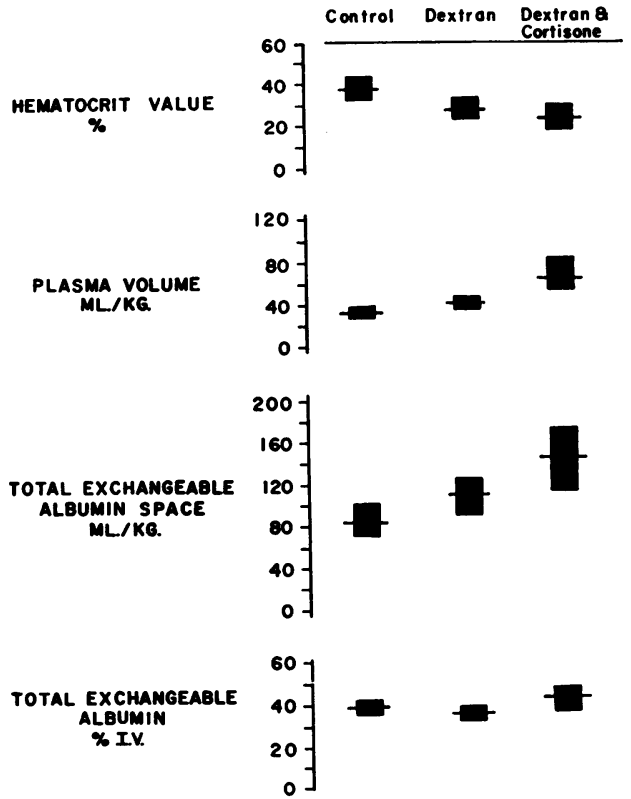

Fig. 3. Albumin distribution. The mean values (horizontal lines) and ranges (solid bars) for hematocrit value, plasma volume, total exchangeable albumin space and per cent of total exchangeable albumin located intravascularly during control, dextran and dextran and cortisone periods. See text and Table I. 
ance as well as the direction of change in albumin degradation and synthesis during the equilibration period. Previous reports have dealt adequately with the use of albumin- $\mathrm{I}^{131}$ as a tracer for endogenous albumin metabolism in both steady and nonsteady states $(10,11,13,15-19)$.

The significance of the differences between the mean values was determined according to the $t$ test (20).

\section{RESULTS}

Data pertaining to albumin distribution are summarized in Table $I$ and Figures 2 and 3. Weights of the animals showed no specific trend throughout any portion of the study. During dextran administration, mean hematocrit values declined in 12 animals by 27.6 per cent while the plasma volume increased by 23.2 per cent. Following institution of cortisone treatment in the dextran-treated animals, the mean hematocrit value decreased further by 16.5 per cent and plasma volume increased an additional 59.5 per cent. These changes in hematocrit values and plasma volume suggest a decrease in red cell mass or shrinkage of erythrocytes after dextran treatment and an increase in red cell production with cortisone treatment. However, alterations in the intravascular distribution of red cells and plasma could explain these findings as well. The mean apparent total exchangeable albumin "space" increased by 33.1 per cent on dextran treatment and a further 28.5 per cent increase was observed upon the addition of cortisone.

Significant changes in the intravascular-extravascular partition of albumin occurred. In control animals, $38.2 \pm 0.5$ per cent of the total albumin pool was located within the plasma space.
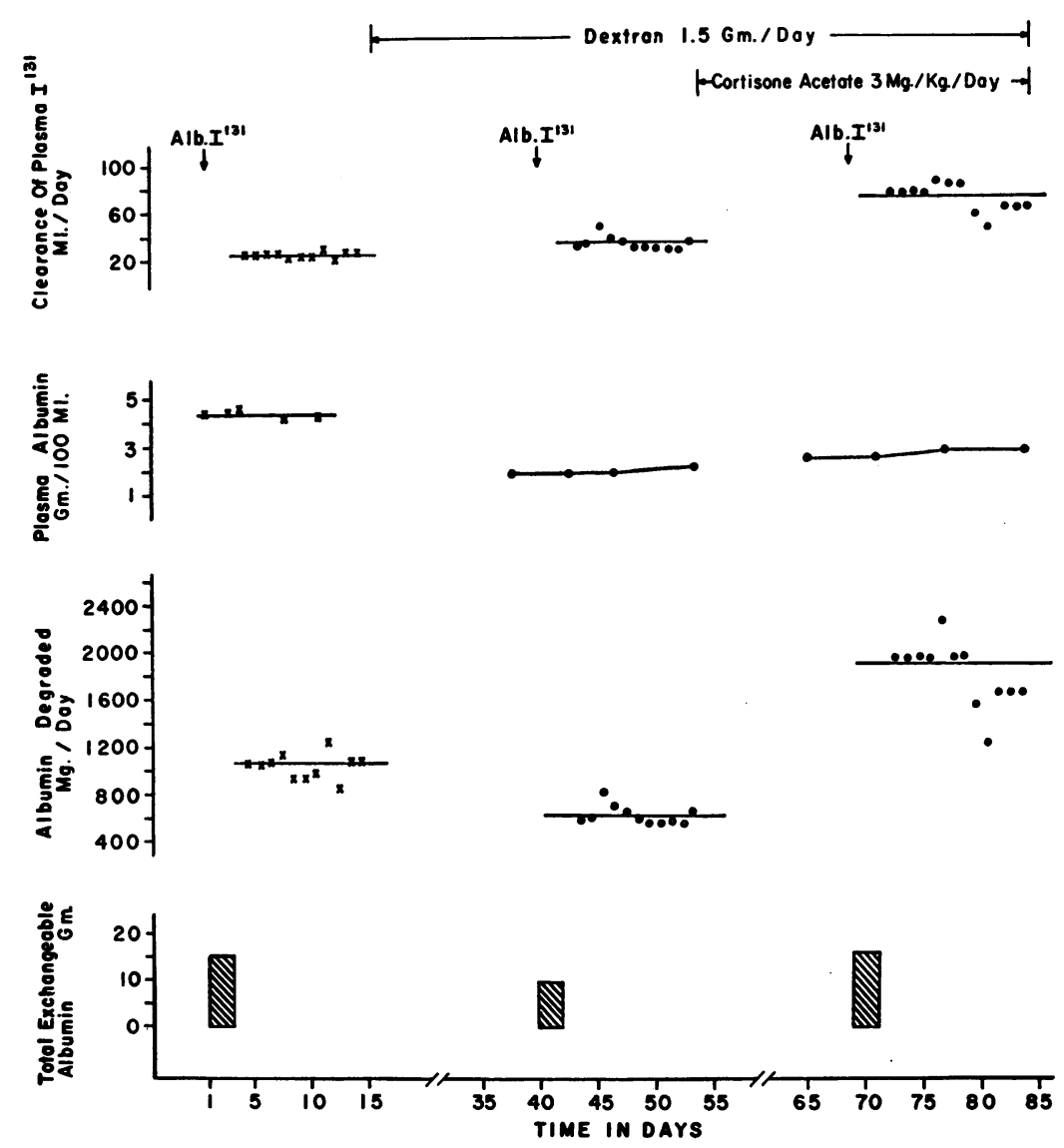

Fig. 4. Typical animal experiment (Rabbit 10). Following dextran administration, a slight rise in the renal clearance of plasma- ${ }^{181}$ occurred; plasma albumin concentration, albumin degradation and the exchangeable albumin pool decreased. Upon the addition of cortisone, the clearance of plasma$\mathrm{I}^{131}$ rose considerably, plasma albumin concentration rose slightly, and there was an increase in albumin degradation and the exchangeable albumin pool. 


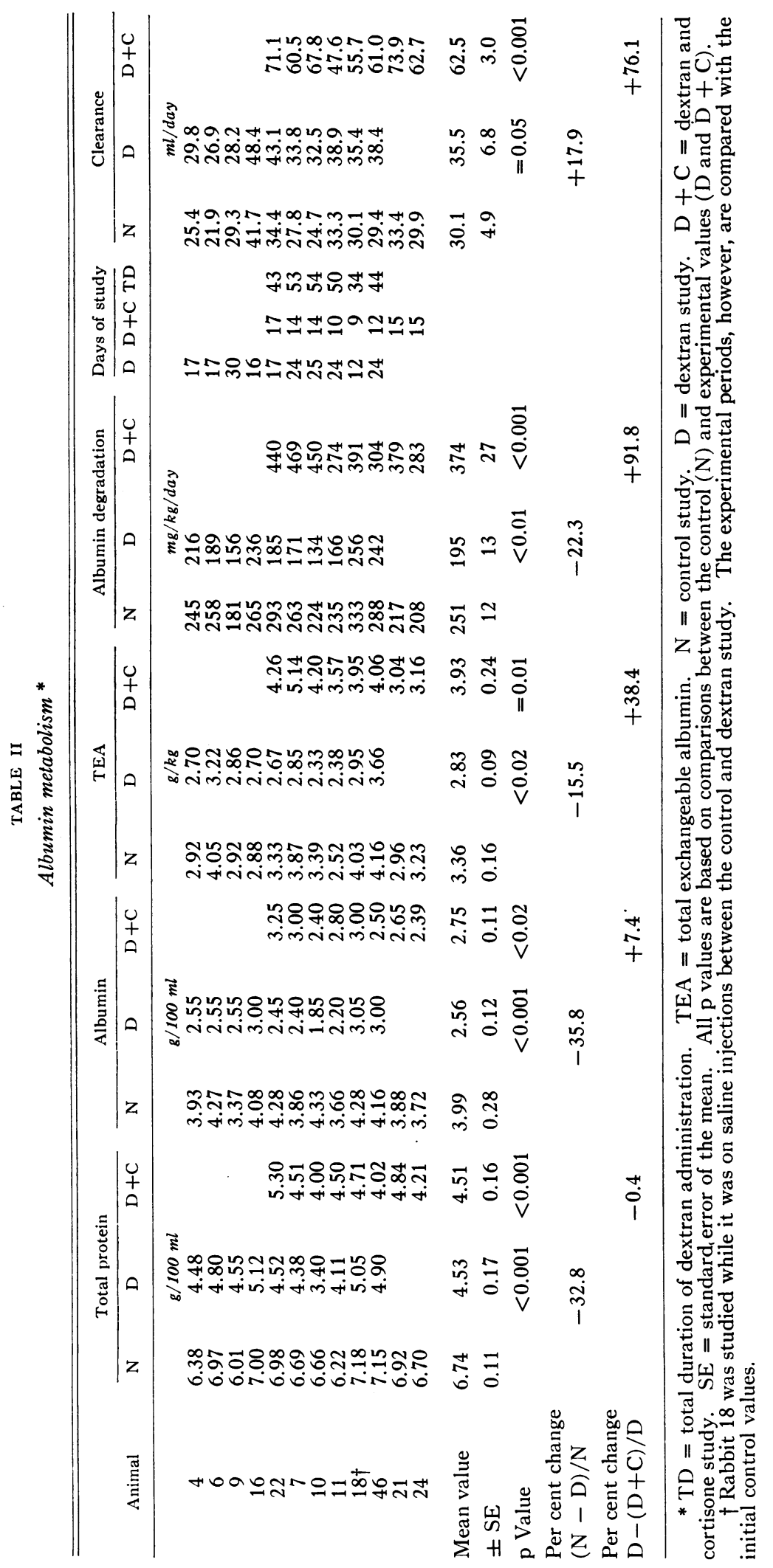




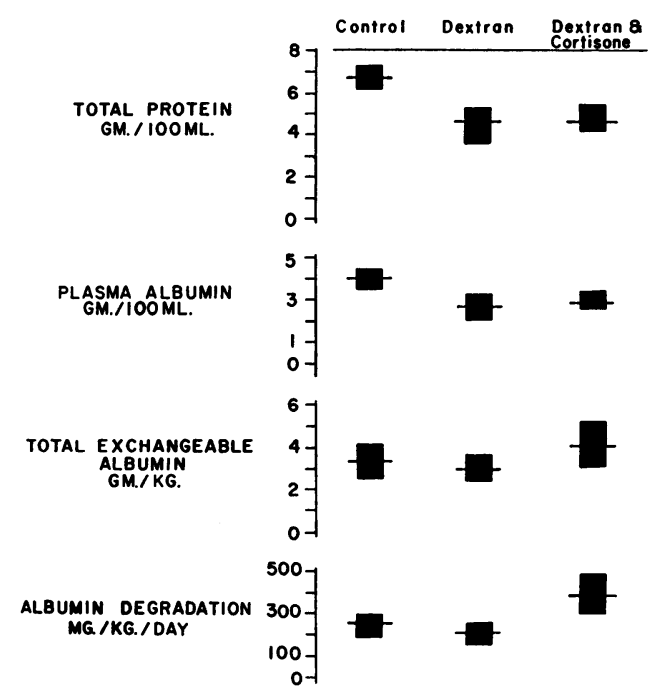

Fig. 5. Albumin metabolism. The mean values (horizontal lines) and ranges (solid bars) for total protein, albumin concentration, total exchangeable albumin and albumin degradation during control, dextran, and dextran and cortisone periods. See text and Table II.

Following the administration of dextran, this fraction decreased slightly to $35.3 \pm 1.0$ per cent, and in animals receiving cortisone and dextran the intravascular compartment increased to 43.3 \pm 1.7 per cent of the total exchangeable albumin.

The data for albumin metabolism are shown in Table II and Figures 4 and 5. After dextran ad- ministration, the mean total plasma protein fell 32.8 per cent, with essentially no change after cortisone therapy. Dextran administration resulted in an average decrease in albumin concentration of 35.8 per cent, while plasma globulin fell by only 28.4 per cent. This finding does not confirm previous reports which indicated a greater fall in the globulin than in the albumin fraction $(2,3,21)$. After cortisone administration, the mean albumin concentration actually rose by 7.4 per cent. The mean total exchangeable albumin pool declined 15.5 per cent after dextran administration and rose 38.4 per cent upon the addition of cortisone.

A decrease in albumin degradation of 22.3 per cent was observed following the administration of dextran. Upon the addition of cortisone, albumin degradation increased by a mean of 49.0 per cent over control values and 91.8 per cent over prior dextran values. ${ }^{3}$ Dextran infusions resulted not

3 The effects of combined dextran and cortisone acetate administration were calculated after the rabbits received cortisone acetate for 9 to 17 days, and the data were derived from the third injection of albumin- $I^{131}$. In Rabbits 10,18 and 46 , daily observations on the excretion of $\mathrm{I}^{131}$ derived from the second dose of tracer albumin were continued after the start of cortisone acetate administration. In these 3 rabbits the excretion of $\mathrm{I}^{131}$, corrected for the fraction of the second dose remaining within the animal, rose rapidly and after 4 to 8 days

TABLE III

Albumin distribution and metabolism *

\begin{tabular}{|c|c|c|c|c|c|c|c|c|c|c|c|c|}
\hline \multirow[b]{2}{*}{ Animal } & \multicolumn{2}{|c|}{ Weight } & \multicolumn{2}{|c|}{ Hematocrit } & \multicolumn{2}{|c|}{ Plasma volume } & \multicolumn{2}{|c|}{ TEAS } & \multicolumn{2}{|c|}{$\begin{array}{l}\text { Albumin } \\
\text { partition }\end{array}$} & & \\
\hline & $\mathrm{N}$ & $\mathrm{E}$ & $\mathrm{N}$ & $\mathrm{E}$ & $\mathrm{N}$ & $\mathrm{E}$ & $\mathrm{N}$ & $\mathrm{E}$ & $\mathrm{N}$ & $\mathrm{E}$ & & \\
\hline & \multicolumn{2}{|c|}{$\mathrm{kg}$} & \multicolumn{2}{|c|}{$\%$} & \multicolumn{2}{|c|}{$\mathrm{ml} / \mathrm{kg}$} & \multicolumn{2}{|c|}{$m l / k g$} & \multicolumn{2}{|c|}{ \% intravascular } & & \\
\hline $4 \dagger$ & 4.08 & 4.54 & 36.8 & 39.3 & 27.9 & 26.0 & 74.5 & 73.0 & 37.4 & 35.5 & & \\
\hline $6 \dagger$ & 3.63 & 4.08 & 38.6 & 37.5 & 37.8 & 34.9 & 94.5 & 97.0 & 40.1 & 35.5 & & \\
\hline $18 \ddagger$ & 3.87 & 3.87 & 43.0 & 40.0 & 33.6 & 34.6 & 93.4 & 96.0 & 36.6 & 35.9 & & \\
\hline $60 \ddagger$ & 5.91 & 6.14 & 37.8 & 38.8 & 33.5 & 33.9 & 88.6 & 85.6 & 37.6 & 39.4 & & \\
\hline & \multirow{2}{*}{\multicolumn{2}{|c|}{ Total protein }} & & & & & & & & & & nce \\
\hline & & & \multicolumn{2}{|c|}{ Albumin } & \multicolumn{2}{|c|}{ TEA } & \multicolumn{2}{|c|}{$\begin{array}{l}\text { Albumin } \\
\text { degradation }\end{array}$} & \multicolumn{2}{|c|}{ Days of study } & $\mathrm{N}$ & $\mathrm{E}$ \\
\hline & \multicolumn{2}{|c|}{$\mathrm{g} / 100 \mathrm{ml}$} & \multicolumn{2}{|c|}{$\mathrm{g} / 100 \mathrm{ml}$} & \multicolumn{2}{|c|}{$\mathrm{g} / \mathrm{kg}$} & \multicolumn{2}{|c|}{$m g / k g / d a y$} & & & \multicolumn{2}{|c|}{$m l / d a y$} \\
\hline $4 \dagger$ & 6.38 & 6.47 & 3.93 & 4.24 & 2.92 & 3.10 & 245 & 219 & & & 25.4 & 23.5 \\
\hline $6 \dagger$ & 6.97 & 6.78 & 4.27 & 4.04 & 4.05 & 3.90 & 258 & 229 & & & 21.9 & 23.2 \\
\hline $18 \ddagger$ & 7.18 & 6.93 & 4.28 & 4.10 & 4.03 & 3.90 & 334 & 333 & 1 & & 30.1 & 29.5 \\
\hline $60 \ddagger$ & 5.82 & 5.84 & 4.00 & 4.04 & 3.60 & 3.50 & 280 & 262 & 2 & & 41.3 & 40.2 \\
\hline
\end{tabular}

$* \mathrm{~N}=$ control. $\mathrm{E}=$ experimental. $\mathrm{TEAS}=$ total exchangeable albumin space. $\mathrm{TEA}=$ total exchangeable albumin.

† Received no treatment during experimental periods which followed by 6 weeks (Rabbit 4) and 8 weeks (Rabbit 6 ) the discontinuation of dextran treatment in these animals.

$\ddagger$ Received only daily saline injections during experimental period. 
only in a decrease in the amount of albumin degraded but also in a mean decrease of total exchangeable albumin of $530 \mathrm{mg}$ per $\mathrm{kg}$. Thus, while degradation decreased, a diminution in synthesis must have taken place to an even greater extent to result in this loss of total exchangeable albumin. Upon the administration of cortisone, changes in the opposite direction occurrednamely, an increase in degradation and an increase in the exchangeable albumin pool by a mean of $1,100 \mathrm{mg}$ per $\mathrm{kg}$. Thus, during the 9 to 17 days of combined dextran-cortisone treatment, albumin synthesis exceeded degradation to a considerable degree. The clearance of plasma- ${ }^{131}$, resulting from albumin degradation, ${ }^{4}$ averaged $30.1 \pm 4.9 \mathrm{ml}$ per day during the control period. An increase to $35.5 \pm 6.8 \mathrm{ml}$ per day occurred following dextran administration, and a further more marked increase to $62.5 \pm 3.0 \mathrm{ml}$ per day was obtained following the administration of cortisone with dextran.

Concentrations of circulating dextran ranged between 1.2 and $2.1 \mathrm{~g}$ per cent during dextran administration and were not significantly altered in the presence of the expanded plasma volume following cortisone therapy.

Table III indicates the results in two animals given saline infusions and in two animals restudied 6 and 8 weeks, respectively, after discontinuing dextran. Neither group showed any marked changes from the control periods.

Most of the animals in the initial study were followed long enough before reinjection so that an accurate estimate of total excretion of radioactivity could be obtained. Between 93 and 106 per cent of the injected dose was accounted for in urine, stool, withdrawn blood, and that still present in the original total albumin space of distribution. No evidence for a very slowly exchanging albumin compartment, as has been suggested by others (19), was obtained from these studies.

\section{DISCUSSION}

While plasma volume expansion clearly follows the infusion of dextran (2-4), little is known

reached values 10.9 to 21.5 per cent greater than those observed with dextran alone. These results are similar to those previously reported after a single dose of albu$\min -\mathrm{I}^{131}(10)$.

4 Proteinuria was not observed and the urinary $\mathrm{I}^{131}$ activity was not precipitable with trichloroacetic acid. concerning the effects of dextran infusions upon the distribution and metabolism of plasma proteins. The plasma protein pool has been reported to decrease $(2,3,22)$, to remain essentially unchanged (23), or to increase (24), and while there is disagreement as to whether albumin or globulin is more affected by dextran infusion, the plasma concentrations of both have been noted to decrease $(2-6,21-25)$.

In the present studies, dextran produced the expected plasma volume expansion and also an expansion of the apparent volume for albumin distribution. Plasma albumin concentration fell, and there was a shift of plasma albumin to extravascular sites. Albumin degradation decreased and albumin synthesis decreased even further, leading to a decrease in total exchangeable albumin. The diminished quantity of albumin degraded in the presence of dextran may be related to the lowered plasma albumin concentration, pool size, or both. Precisely the opposite result has been observed with an elevated plasma albumin level and total exchangeable albumin pool (26).

That albumin synthesis was not stimulated, but actually decreased in the presence of low albumin concentration and pool size, indicates that the mechanism responsible for albumin synthesis is not sensitive to low albumin levels per se and suggests that the mechanism might be sensitive to oncotic pressure. The frequently observed fall in albumin concentration accompanying elevations in globulin concentration is in agreement with this concept (27). In the present studies, the decrease in plasma oncotic pressure resulting from the decrease in albumin concentration was not compensated for by the increase in oncotic pressure calculated from the measured concentration of circulating dextran. This conclusion is deduced as follows. It has been reported that the osmotic pressure of serum albumin at $\mathrm{pH} 7.4$ and at concentrations less than $5 \mathrm{~g}$ per $100 \mathrm{ml}$ obeys van't Hoff's law after correction for the GibbsDonnan effect $(28,29)$. Thus, the observed decrease in plasma albumin concentration of $1.43 \mathrm{~g}$ per cent following dextran infusions results in a calculated decrease in the plasma colloid osmotic pressure of $7.6 \mathrm{~mm} \mathrm{Hg}$. Using the maximal value observed ( $2 \mathrm{~g}$ per $100 \mathrm{ml}$ ) for plasma dextran concentration and assuming that the average 
molecular weight of the circulating dextran was 188,000 , the colloid osmotic pressure contributed by dextran alone would be only $2.1 \mathrm{~mm} \mathrm{Hg}$. However, the site of albumin production is most likely in direct contact with extracellular fluid rather than with plasma, and the results of these studies indicate that the total extravascular albumin suffered a lesser reduction than total plasma albumin during dextran treatment (Table IV). Unless the interstitial space increased even more than did the plasma volume, these results would indicate that the interstitial concentration of albumin suffered a lesser reduction than did the plasma albumin concentration. Thus it is possible that in certain critical areas adjacent to or within sites of albumin synthesis, the sum of interstitial dextran and albumin could have resulted in a colloid osmotic pressure high enough to inhibit albumin synthesis. ${ }^{5}$

Upon the addition of cortisone, albumin distribution and metabolism were again altered. Plasma volume was nearly doubled and plasma albumin concentrations rose (in four of six rabbits) indicating a return of albumin from extravascular locations to the plasma. The absence of any change in plasma dextran concentration, in spite of a marked increase in plasma volume during combined dextran-cortisone therapy, suggests that cortisone probably mobilized extravascular dextran as well. Cortisone administration has previously been shown to result in increased albumin catabolism (10) and this effect was observed again; however, albumin synthesis increased to a greater extent, resulting in a total exchangeable albumin pool even larger than that observed during the control study.

In the presence of dextran and a low albumin concentration, cortisone administration not only resulted in a more marked increase in albumin synthesis than when it was given without prior dextran therapy, but also caused a greater shift of extravascular albumin to the plasma than had been observed previously in the absence of dex-

\footnotetext{
${ }^{5}$ It is recognized that if a disproportionately large number of smaller dextran molecules were present, then the calculated colloid osmotic pressure due to dextran would be higher than the computed value given above. However, such a change in the colloid osmotic pressure would seem to be applicable to both plasma and interstitial fluid and would not tend to refute the above hypothesis.
}

TABLE IV

Albumin partition

\begin{tabular}{|c|c|c|c|}
\hline & Control & Dextran & $\begin{array}{c}\text { Dextran } \\
+ \\
\text { cortisone }\end{array}$ \\
\hline \multicolumn{4}{|c|}{ Intravascular albumin } \\
\hline $\begin{array}{l}\text { Mean value, } \mathrm{g} \\
\text { Change, } \%\end{array}$ & 6.2 & $\begin{array}{r}4.9 \\
-21.0\end{array}$ & $\begin{array}{r}8.1 \\
+65.4\end{array}$ \\
\hline \multicolumn{4}{|c|}{ Extravascular albumin } \\
\hline $\begin{array}{l}\text { Mean value, } \mathrm{g} \\
\text { Change, } \%\end{array}$ & 10.1 & $\begin{array}{r}9.0 \\
-10.7\end{array}$ & $\begin{array}{r}10.6 \\
+17.8\end{array}$ \\
\hline
\end{tabular}

tran (10). In addition, cortisone therapy has been reported to cause an increase in extracellular volume $(30,31)$ even in the absence of weight gain (30). Thus it may be suggested that, following cortisone administration, there might have been a reversal of the elevated extravascular colloid concentration postulated under dextran administration, with a resultant augmented stimulus for albumin production. However, until it becomes possible to measure extracellular colloid concentration, these considerations must remain purely speculative.

Other factors must also be considered in attempting to interpret the observed changes in albumin metabolism. The depression of albumin synthesis by dextran might have been due to a specific toxic action unrelated to osmotic activity. However, the rapid return to normal following discontinuation of dextran indicates that such action, if it exists, is readily reversible. While no specific mechanism has been identified as responsible for the observed changes in albumin synthesis, it is clear that, in the presence of dextran, a low albumin concentration is not an adequate stimulus for normal albumin synthesis. Addition of cortisone results in a marked stimulation of albumin synthesis.

\section{SUMMARY}

1. The effects of daily dextran infusions on the distribution and metabolism of albumin- ${ }^{131}$ were studied in 12 female rabbits. Cortisone acetate was administered to 6 of the rabbits after prolonged dextran infusions and to 2 rabbits from the onset of dextran administration. Two rabbits were re-examined 6 and 8 weeks after dextran infusions were discontinued, and the effects of saline infusions were studied in 2 additional rabbits. 
2. Under the influence of dextran, total exchangeable albumin was diminished, while plasma volume and total apparent space for albumin increased. The rate of albumin degradation decreased by 22.3 per cent and the rate of albumin synthesis by at least this much in the presence of a lowered plasma albumin concentration.

3. Upon the addition of cortisone, the plasma volume and total apparent space for albumin distribution increased markedly, with a shift of albumin stores from extravascular to intravascular sites. Albumin degradation increased 49 per cent over control values and 91.8 per cent above the value obtained during dextran infusions alone. The increment in albumin synthesis was probably more marked, since the total exchangeable albumin pool increased in the face of the increase in albumin degradation. Albumin synthesis seems unrelated to albumin levels per se.

4. Albumin synthesis may be regulated by the level of oncotic pressure in certain critical locations adjacent to or within sites of albumin synthesis.

\section{ACKNOWLEDGMENTS}

The authors wish to express appreciation to Dr. Solomon Berson for his helpful advice. They also express appreciation to Miss Margaret Tobin for secretarial assistance, to Miss Josephine Neglia and Mr. Orazio Masca for the illustrations, and to Mr. Robert Scipione, Mr. Hansel McGee, Mr. Ramon Flores and Mr. John Tolbert for technical assistance.

\section{REFERENCES}

1. Whipple, G. H., and Madden, S. C. Hemoglobin plasma protein and cell protein-their interchange and construction in emergencies. Medicine (Baltimore) 1944, 23, 215.

2. Jaenike, J. R., and Waterhouse, C. Metabolic and hemodynamic changes induced by the prolonged administration of dextran. Circulation 1955, 11, 1.

3. Carbone, J. V., Uzman, L. L., and Plough, I. C. Changes in serum proteins produced by infusions of dextran. Proc. Soc. exp. Biol. (N. Y.) 1955, 90, 68.

4. Thorsen, G. Dextran as a plasma substitute. Lancet 1949, 1, 132.

5. Bull, J. P., Ricketts, C., Squire, J. R., Maycock, W. d'A, Spooner, S. J. L., Mollison, P. L., and Paterson, J. C. S. Dextran as a plasma substitute. Lancet 1949, 1, 134.

6. Rosenquist, H., and Thorsen, H. G. R. Macrodex in the treatment of extensive burns. Arch. Surg. (Chicago) 1951, 62, 524.
7. Bjфrneboe, M., and Schwartz, M. Investigations concerning the changes in serum proteins during immunization. The cause of hypoalbuminemia with high gamma globulin values. J. exp. Med. 1959, 110, 259.

8. Franklin, E. F., Rothschild, M. A., Oratz, M., and Schreiber, S. S. Unpublished observations.

9. Bjфrneboe, M. Studies on the serum proteins in hepatitis. I. The relation between serum albumin and serum globulin. Acta med. scand. 1946, 123, 393.

10. Rothschild, M. A., Schreiber, S. S., Oratz, M., and McGee, H. L. The effects of adrenocortical hormones on albumin metabolism studied with albu$\min \mathrm{I}^{131}$. J. clin. Invest. 1958, 37, 1229.

11. Berson, S. A., Yalow, R. S., Schreiber, S. S., and Post, J. Tracer experiments with $\mathrm{I}^{131}$ labeled human serum albumin: Distribution and degradation studies. J. clin. Invest. 1953, 32, 746.

12. Roe, J. H. The determination of dextran in blood and urine with anthrone reagent. J. biol. Chem. 1954, 208, 889.

13. Rothschild, M. A., Bauman, A., Yalow, R. S., and Berson, S. A. The effect of large doses of desiccated thyroid on the distribution and metabolism of albumin- ${ }^{131}$ in euthyroid subjects. J. clin. Invest. 1957, 36, 422.

14. Berson, S. A., and Yalow, R. S. Quantitative aspects of iodine metabolism. The exchangeable organic iodine pool, and the rates of thyroidal secretion, peripheral degradation and fecal excretion of endogenously synthesized organically bound iodine. J. clin. Invest. 1954, 33, 1533.

15. Berson, S. A., and Yalow, R. S. Distribution and metabolism of $\mathrm{I}^{131}$ labeled proteins in man. Fed. Proc. 1957, 16, suppl. 1, 13S.

16. Bauman, A., Rothschild, M. A., Yalow, R. S., and Berson, S. A. Distribution and metabolism of $\mathrm{I}^{131}$ labeled human serum albumin in congestive heart failure with and without proteinuria. J. clin. Invest. 1955, 34, 1359.

17. Reeve, E. B., and Roberts, J. E. The kinetics of the distribution and breakdown of $\mathrm{I}^{131}$-albumin in the rabbit. Observations on several mathematical descriptions. J. gen. Physiol. 1959, 43, 415.

18. Zizza, F., Campbell, T. J., and Reeve, E. B. The nature and rates of excretion of radioactive breakdown products of $\mathrm{I}^{131}$-albumin in the rabbit. J. gen. Physiol. 1959, 43, 397.

19. Lewallen, C. G., Berman, M., and Rall, J. E. Studies of iodo-albumin metabolism. I. A mathematical approach to the kinetics. J. clin. Invest. 1959, 38, 66.

20. Mainland, D. Elementary Medical Statistics. Philadelphia, W. B. Saunders, 1952, pp. 147-157.

21. Morrison, A. B. The effect of dextran on serum proteins and serum cholesterol. Quart. J. exp. Physiol. 1956, 41, 51.

22. Rothschild, M. A., Oratz, M., and Schreiber, S. S. The effect of dextran on the distribution and me- 
tabolism of albumin- $\mathrm{I}^{131}$ (abstract). Clin. Res. 1960, 8, 34.

23. Semple, R. E. Effect of small infusions of various dextran solutions on normal animals. Amer. J. Physiol. 1954, 176, 113.

24. Hammarsten, J. F., Heller, B. I., and Ebert, R. V. The effects of dextran in normovolemic and oligemic subjects. J. clin. Invest. 1953, 32, 340.

25. Zizza, F. Effect of parenteral dextran solution on metabolism of plasma albumin. Fed. Proc. 1959, 18, 175.

26. Rothschild, M. A., Oratz, M., Schreiber, S. S., and Wimer, E. Unpublished observations.

27. Ogryzlo, M. A., Maclachlan, M., Dauphinee, J. A., and Fletcher, A. A. The serum proteins in health and disease. Filter paper electrophoresis. Amer. J. Med. 1959, 27, 596.
28. Scatchard, G., Batchelder, A. C., and Brown, A. Chemical, clinical, and immunological studies on the products of human plasma fractionation. VI. The osmotic pressure of plasma and of serum albumin. J. clin. Invest. 1944, 458, 23.

29. Cohn, E. J., Oncley, J. L., Strong, L. E., Hughs, W. L., Jr., and Armstrong, S. H., Jr. Chemical, clinical and immunological studies on the products of human plasma fractionation. I. The characteristics of the protein fractions of human plasma. J. clin. Invest. 1944, 23, 417.

30. Levitt, M. F., and Bader, M. E. Effect of cortisone and $\mathrm{ACTH}$ on fluid and electrolyte distribution in man. Amer. J. Med. 1951, 715, 11.

31. Walser, M., Seldin, D. W., and Burnett, C. H. Blood volume and extracellular fluid volume during administration of ACTH and cortisone. Amer. J. Med. 1955, 18, 454. 